\title{
Chinese Culture in English Translation of Agriliterature
}

\author{
Jianling Huang \\ College of Foreign Languages, Shandong Agricultural University, Taian, China \\ Email: Elleh@126.com
}

How to cite this paper: Huang, J.L. (2017) Chinese Culture in English Translation of Agriliterature. Agricultural Sciences, 8, 1114-1119.

https://doi.org/10.4236/as.2017.810081

Received: August 26, 2017

Accepted: October 20, 2017

Published: October 23, 2017

Copyright $\odot 2017$ by author and Scientific Research Publishing Inc. This work is licensed under the Creative Commons Attribution International License (CC BY 4.0).

http://creativecommons.org/licenses/by/4.0/

\begin{abstract}
China is a large agricultural country, developing fast in agriscience (agricultural science). However, the translation of agriliterature (agricultural literature) and its study lag far behind. Eco-translatology, describing the process of translating as Adaption and Selection, offers the guide to the translation of this field. In this paper, a study on the translation of agriliterature is performed with focus on the influence of Chinese culture from the perceptive of eco-translatology, from which implications and suggestions are derived for translators, scholars and scientists concerned.
\end{abstract}

\section{Keywords}

Chinese Culture, Agriliterature, Translation, Eco-Translatology

\section{Introduction}

China is a large agricultural country, with agriscience as the main branch in natural science. As agriscience develops fast, there are increasingly frequent international exchanges and communications between scholars or experts in this field. However, the English translation from Chinese agriliterature with Chinese cultural factors seems to be not so satisfactory. Still worse, the study, esp. from cultural angle, on the translation, lags far behind now. Fortunately, eco-translatology, describing the process of translating as Adaption and Selection [1], offers guide to the translation of agriliterature. Therefore, based on eco-translatology, the study on the translation of agriliterature is carried out from cultural dimensions to explore how Chinese culture should be treated and translated properly in the translation eco-environment of agriliterature, from which implications and suggestions can be derived for scholars and experts as well as translators in the field. 


\section{Agriliterature and Chinese Culture}

Broadly, agriculture consists mainly of four areas: farming and planting, livestock breeding, forestry and fishery, while agriliterature refers to the academic works on the study of agriculture such as books, journals, overviews, papers, abstracts, reports, etc. Linguistically, agriliterature is featured typically in the style of scientific expressions as being objective and accurate, formal and concise, its target readers being scholars, experts or translators in this field, who own the basic knowledge of agriculture and have academic interest in agriscience. However, the fact that the two languages, Chinese and English, in the translation of agriliterature come from different language systems and cultures brings difficulties to the translations of agriliterature, and its academic communications.

China, as a large agricultural country, has a history of agricultural development. Since agriculture is a lifeline of the country, it cannot stand alone from Chinese tradition and culture. In other words, Chinese culture cannot but influxes and influences agriculture. As well known, the culture differs greatly between the east and the west in many aspects, including agricultural development, history, production, cultural ideas or ideology, etc. Such differences are found in expressions of agriliterature as study purposes, methods, results and its explanations, conclusions etc. When it comes to the exchanges between people of different cultures, there is no doubt that different cultures will confront and collide with each other, and this interferes the translators with his judgments and expressions, which evidently causes difficulties again to the translations of agriliterature. To gain a successful translation, it is important to be familiar and careful with both the cultures and the two languages in translation, because only with cultural influence and cultural background, can words and expressions have meaning, as Nida put it [2].

\section{Theoretical Guide: Eco-Translatology}

Eco-translatology, emerged in the early $21^{\text {st }}$ century [1], is to explore translating process on the basis of Darwinian evolutionary idea of natural selection. Until now many papers and articles related to eco-translatology have been published. According to eco-translatology mainly from $\mathrm{Hu}$ Genshen [3], the process of translating is described as the process of Adaption and Selection, during which translators's adaptation is made to the specific eco-environment of the source text and then his selection of the final target text is produced based on the eco-environment of the translation, including such factors as translators, readers, languages, societies, cultures concerned, etc. The principle of eco-translation is briefly summarized as multi-dimensional adaptations and natural selections, while its methods lie mainly in three dimensional transformations, namely, linguistic, cultural and communicative dimensions. On the surface, translation is the exchange of two different languages, but profoundly translation is an exchange of cultures, a cross-cultural communication. There is no exception in the translation 
of agriliterature. Therefore, it is essential to pay due attention to the cultures of the two languages, so as to adapt culturally to translation eco-environment of agriliterature and make natural selection of the target text fit for English text environment, finally to achieve the purpose of conveying the agricultural messages accurately. A detailed analysis is made in the study from three cultural dimensions below around the English translation of Chinese agriliterature.

\section{Chinese Culture in English Translation of Agriliterature}

\subsection{The Dimensions of Time and Space}

As discussed above, Chinese agriliterature carries heavy Chinese cultural factors, firstly in dimensions of time and space. Agriscience is closely related to local culture in time and space, so it has strong dimensions of time and space, and this can be reflected in its literature. Besides, for convenience, habit or efficiency in exchange of local speakers, time and space are often expressed in special forms, shortened or abbreviated even omitted, which is more difficult for readers of English culture to understand. Without due attention to the cultural factors of time and space and their special expressions, such translation could not succeed because the cultural factors are ignored first in understanding, than in expression. As a result, it is not accepted by English readers and is not an adaptive selection of the translation eco-environment. Take example of Jiang, Zhe in Chinese pinyin. The two abbreviations often appear in the agriliterature about the two southern provinces of Jiangsu, Zhejiang for the sake of convenience or efficiency in communication of Chinese colleagues. But when it is read by English readers, this easily produces difficulties and confusions about the local places, because their translations fail to offer sufficient information to fit the English eco-environment. To meet the requirements of target readers in comprehension, a better selection of translation should turn to its full names as Jiangsu, Zhejiang provinces. In this way, the message on agriliterature can be passed on accurately to English readers. Similarly the following two examples of places with numbers also needs careful treatment, Sanjiang, Lianghu, literally referring to three rivers and two provinces. The translation three rivers might as well go further in explanation with added information as follows, the Heilong River-the Songhua River-the Wusuli River in northeast China's Heilongjiang province, while two provinces should be expressed specifically as Hunan province, Hubei province. However, if the term Sanjiang, Lianghu are the focus of the study and appear frequently in later part of context, it can be accepted to be translated literally in its simple form Sanjiang, Lianghu with no problem in conveying its rich meaning to its English readers in its translation eco-environment, and this also goes with the economic principle in language [4].

As for the eco-translation of time dimension, firstly an expression of historic period is taken: Nansong, literally meaning South Song, which is not true of Chinese history eco-translatologically in expression. In Chinese history of Song 
Dynasty (from 960 to 1129 AD), there were two stages, known as in Chinese pinyin Beisong, literally Northern Song and Nansong, literally Southern Song. They were divided and named as South or North in geogrophy, but the truth is chronologically named that Beisong started early from 960 to 1127 AD, Nansong the following two years, i.e., from 1127 to 1129AD. According to Qimin Yao $S h u$, a book on agricultural history written by ancient scientist Jia Sixie (533 544), and to eco-translatology, Beisong should be translated into the earlier Song Dynasty, Nansong the later Song Dynasty. Such translations can be faithful to its meaning and be understood and accepted by English readers and so is an adaptive selection in the translation eco-environment.

\subsection{The Dimensions of Measurement Units}

Measurement units are indispensable to scientific text, so is to agriliterature. Chinese measurements carry heavy Chinese culture. China, as a large, old, agricultural country, creates many unique expressions in measurement of land area, length, weight, money, etc. For example, Chinese unit $M u$ is used for acreage of land area; similarly, Zhang, Chi, Cun for length: Jin, liang, Dan for weight. The units in the two languages are different in value. With literal and mechanical translation, the translation of agriliterature easily causes misunderstanding. The probable reason is that cultural differences on units are ignored, which will affect, even distort the comprehension of its data, its results and conclusions of the study, causing the loss of its research value. In this case, great importance should be attached to the exchange rates of the different units of the two languages. For example, $1 \mathrm{Ha}$ (hectare) $=15 \mathrm{Mu}, 1 \mathrm{Dan}=50 \mathrm{~kg}$. Clearly it is vital for translators to be strongly aware of difference of measurements between Chinese and English, and transfer and convert Chinese measurements into the international English ones by doing mathematical calculations according to their exchange rate, in order to adapt to the target eco-environment.

Concerning the units of money, special attention should be paid in its conversion. In Chinese, R.M.B. (short for Renminbi) is adopted as money unit, but the exchange rate in money unit with other money units of different cultures varies with time, and more complicatedly, also with the international positions of the two cultures. It symbolizes the sovereign rights of the country. The adaptive selection in translation is that Chinese money units yuan or R.M.B. may appear in literature, without translation into English units, dollars or pounds. But for the sake of English readers, it is necessary to do additional translation of the exchange rate in English, in order to adapt to the English eco-environment.

Seen from the above, it is significant culturally, scientifically and also politically to treat properly Chinese culture in the English translation of agriliterature.

\subsection{Dimension of Seasons: Twenty-Four Jieqi (Twenty-Four Solar Items)}

As mentioned above, China is an old, agricultural country, with a five-thousand- 
year history. Her long history, rich in agricultural elements, the typical one of which is Jieqi, Chinese solar terms. In ancient China, working people named the track of sun revolving around the earth as Huangdao, the position of sun movement, then the whole solar year could be divided into 24 periods, and this is so-called 24 solar terms or JieQi, with purpose of offering guide to farming activities. Later Jieqi was widely spread in China, usu. in the form of proverbs. As a result, a farming tradition based on Jieqi was formed and handed down to present time. Jieqi, with characteristics of Chinese agricultural elements, represents the wisdom of Chinese ancient people and bears the deep agricultural heritage. Its English readers, with little idea of Jieqi, certainly have great difficulty in comprehension of such literature. So the common translation strategy is to transfer Jieqi directly into its date to convey the farming time. Due to the date of Jieqi expressed in Chinese solar calendar, there is a slight variation of date, indicating the different dates every year in Chinese solar calendar. Besides, Chinese solar calendar happens to match the international calendar, so Jieqi can be expressed in the Gregorian calendar in translation. True that cultural message is not embodied in such translation in this example, but it succeeds in conveying its agriscience message properly, so eco-translatologically it is a reasonable and adaptive selection. Occasionally 24 Jieqi itself is mentioned in sentences or in proverbs, where more explanations should be paid to its cultural sources or implications, besides the additional note of dates.

For reference, the English version of the 24 Jieqi with time ranges are listed in Table 1, based on sources concerned [5].

Table 1. 24 Jieqi and their English Translations

\begin{tabular}{|c|c|c|c|}
\hline Chunjie Spring & Xiaji Summer & Qiuji Autumn & Dongji Winter \\
\hline $\begin{array}{l}\text { Lichun (Feb. 3-5) } \\
\text { The Beginning of Spring }\end{array}$ & $\begin{array}{l}\text { Lixia (May 5-7) } \\
\text { The Beginning of } \\
\text { Summer }\end{array}$ & $\begin{array}{l}\text { Liqiu (Aug. 7-9) } \\
\text { The Beginning of } \\
\text { Autumn }\end{array}$ & $\begin{array}{l}\text { Lidong (Nov. } 7-8 \text { ) } \\
\text { The Beginning of Winter }\end{array}$ \\
\hline $\begin{array}{c}\text { Yushui (Feb. 18-20) } \\
\text { Rain Water }\end{array}$ & $\begin{array}{l}\text { Xiaoman } \\
\text { (May 20-22) } \\
\text { Grain Buds }\end{array}$ & $\begin{array}{c}\text { Chushu (Aug. 22-24) } \\
\text { End of Heat }\end{array}$ & $\begin{array}{c}\text { Xiaoxue } \\
\text { (Nov. 22-23) } \\
\text { Slight Snow }\end{array}$ \\
\hline $\begin{array}{l}\text { Jingzhe (Mar. 5-7) } \\
\text { The Wakening of Insects }\end{array}$ & $\begin{array}{l}\text { Mangzhong } \\
\text { (Jun. 5-7) } \\
\text { Grain in Ear }\end{array}$ & $\begin{array}{c}\text { Bailu (Sep. 7-9) } \\
\text { White Dew }\end{array}$ & $\begin{array}{c}\text { Daxue (Dec. 6-8) } \\
\text { Heavy Snow }\end{array}$ \\
\hline $\begin{array}{c}\text { Chunfen (Mar. 21-22) } \\
\text { Vernal Equinox }\end{array}$ & $\begin{array}{l}\text { Xiazhi (Jun. 21-22) } \\
\text { Summer Solstice }\end{array}$ & $\begin{array}{c}\text { Qiufen } \\
\text { (Sep. 22-24) } \\
\text { Autumn Equinox }\end{array}$ & $\begin{array}{c}\text { Dongzhi } \\
\text { (Dec. 21-23) } \\
\text { Winter Solstice }\end{array}$ \\
\hline $\begin{array}{l}\text { Qingming (Apr. 4-6) } \\
\text { Pure Brightness }\end{array}$ & $\begin{array}{l}\text { Xiaoshu (Jul. 6-8) } \\
\text { Slight Heat }\end{array}$ & $\begin{array}{c}\text { Hanlu (Oct. 8-9) } \\
\text { Cold Dew }\end{array}$ & $\begin{array}{l}\text { Xiaohan (Jan. 5-7) } \\
\text { Slight Cold }\end{array}$ \\
\hline $\begin{array}{c}\text { Guyu (Apr. 19-21) } \\
\text { Grain Rain }\end{array}$ & $\begin{array}{c}\text { Dashu (Jul. 22-24) } \\
\text { Great Heat }\end{array}$ & $\begin{array}{c}\text { Shuangjiang } \\
\text { (Oct. 23-24) } \\
\text { Frost's Descent }\end{array}$ & $\begin{array}{c}\text { Dahan (Jan. 20-21) } \\
\text { Sever Cold }\end{array}$ \\
\hline
\end{tabular}




\section{Conclusion}

According to Text Typology, agriliterature belongs to informative text and its main function is to offer information on agriscience, while eco-translatology emphasizes on the multi-dimensional adaption and selection in the whole eco-environment of translating, typically studied in this paper in time and space, in measurements, and in the twenty-four Jieqi, so cultural influence should not be ignored in conveying the agriscientifc information. Hence, translators of agriliterature should have strong awareness of culture, as well as a good command of languages, rigorous and scientific style, so as to be fit and survive with his or her works in the translation eco-environment. It is hoped that through the research some contributions will be made to the transmission and spread of rich Chinese agriculture and ancient tradition, and the rise of quality in the translation of agriliterature with the application of eco-translatology.

\section{References}

[1] Hu, G.S. (2004) Theoretical Props of the Approach to Translation as Adaptation and Selection. Shanghai Journal of Translators for Science and Technology, 4 40-44.

[2] Nida, E.A. (1993) Language, Culture, and Translating. Foreign Language Education Press, Shanghai.

[3] Hu, G.S. (2010) Relevance, Affinity and Isomorphism between Translational and Natural Ecosystems. Shanghai Journal of Translators for Science and Technology, 4, 1-5.

[4] Huang, J.L. (2012) The Principle of Economy: Writing and Translating Sci-Tech Papers. Science \& Technology Translators, 2, 33-36.

[5] Tian, Y.F. (1993, 2008) A Guide to Translating Agricultural Science These from Chinese into English. The Press of Chengdu University of Science and Technology, Chengdu. 